\title{
ATTRACTION OF Astylus variegatus (GERM.) (COLEOPTERA: MELYRIDAE) BY VOLATILE FLORAL ATTRACTANTS
}

\author{
Maurício Ursi Ventura*; Tania Pereira; Daiane Heloisa Nunes; Iara Cintra de Arruda \\ UEL/CCA - Depto. Agronomia, C.P. 6001 - 86051-970 - Londrina, PR - Brasil. \\ *Corresponding author <mventura@uel.br>
}

\begin{abstract}
The beetle Astylus variegatus (Germ.) (Coleoptera: Melyridae) is frequently found in flowers feeding on pollen. Responses of A. variegatus to volatile floral attractants were studied in common beans (Phaseolus vulgaris L.) fields. Traps originally designed to capture Diabrotica speciosa (Germ.) (Coleoptera: Chrysomelidae), consisted of plastic bottles (2 L) with 150 holes (5-mm diameter) yellow gold painted and containing inside a plastic strip $(3.5 \times 25 \mathrm{~cm})$ with Lagenaria vulgaris $(\mathrm{L}$.) powder $(0.28 \%$ B cucurbitacin - feeding stimulant and arrestant for diabroticites) sprayed with carbaril insecticide. Treatments consisted of 1,4-dimethoxybenzene (one or two dispensers per trap), 1,4dimethoxybenze + indole, 1,4-dimethoxybenzene + cinnameldehyde and control. Volatile average release rates (over ten days) was approximately $32 \mathrm{mg} \mathrm{day}^{-1}$ per dispenser under laboratory conditions. 1,4dimethoxybenzene-lured traps caught significantly more beetles than the control, three and seven days after trap setting. Ten days after the onset of the experiment, there were no differences in number of beetles caught by treatments. Captures were higher in the 1,4-dimethoxybenzene + cinnamaldehyde treatment than in 1,4-dimethoxybenzene only in the first assessment. Adding indole to 1,4dimethoxybenzene did not improve beetle captures.
\end{abstract}

Key words: Diabrotica speciosa, semiochemical, trap

\section{ATRAÇÃO DE Astylus variegatus (GERM.) (COLEOPTERA: MELYRIDAE) POR ATRAENTES FLORAIS VOLÁTEIS}

\begin{abstract}
RESUMO: O besouro Astylus variegatus (Germ.) (Coleoptera: Melyridae) é freqüentemente encontrado em flores onde se alimenta de pólen. Respostas de A. variegatus a atraentes voláteis florais foram estudadas em campos de feijão, Phaseolus vulgaris L. Armadilhas, originalmente desenvolvidas para capturar Diabrotica speciosa (Germ.) (Coleoptera: Chrysomelidae), consistiram de garrafas plástica $(2 \mathrm{~L})$ com 150 perfurações $(5 \mathrm{~mm}$ de diâmetro) pintadas com tinta amarelo ouro contendo no seu interior uma fita plástica $(3,5 \times 25,0 \mathrm{~cm})$ com pó seco de frutos de Lagenaria vulgaris (L.) $(0,28 \%$ de cucurbitacina $\mathrm{B}$ - estimulante alimentar e arrestante para diabroticíneos) pulverizados com inseticida carbaril. Os tratamentos foram: 1,4-dimetoxibenzeno (um ou dois liberadores por armadilha); 1,4dimetoxibenzeno + indol; 1,4-dimetoxibenzeno + cinamaldeído e testemunha (sem volátil). As taxas de liberação dos semioquímicos (por 10 dias) foram de aproximadamente $32 \mathrm{mg} \mathrm{dia}^{-1}$ por liberador em condições de laboratório. Armadilhas iscadas com 1,4-dimetoxibenzeno capturaram mais insetos que a testemunha, três e sete dias após instalação das armadilhas. Dez dias após o início dos experimentos, não foram verificadas diferenças entre os tratamentos, no número de besouros capturados. Capturas foram maiores no tratamento com 1,4-dimetoxibenzeno + cinamaldeído do que no 1,4-dimetoxibenzeno sozinho na primeira avaliação. Adição do indole ao 1,4-dimetoxibenzeno não aumentou as capturas. Palavras-chave: Diabrotica speciosa, semioquímico, armadilha
\end{abstract}

\section{INTRODUCTION}

Melyridae are small to medium size beetles that feed on pollen (Willemstein, 1987). Astylus variegatus (Germ.) (Coleoptera: Melyridae) is a univoltine beetle associated with flowers of native and exotic plants in South America (Matioli et al., 1990).
Beetles were found in several states of Brazil, Paraguay and Argentina (Souza \& Carvalho, 1994). Adults were found from January to June and high temperatures were the main factor associated with the occurrence and movement of beetles in the field (Rossetto \& Rossetto, 1976; Matioli \& Figueira, 1988). Damage caused by adults were reported on 
sorghum panicles in which losses reached 5\% (Rossetto \& Rossetto, 1976).

The life cycle lasts about one year and the larvae live in the soil. Under favorable humidity conditions (dry season), the larvae damage seeds and seedlings mostly in corn (Bianco, 1991). Therapeutic tactics are not available for larval management; seed treatment with insecticides is the suggested measure to control them (Bianco, 1991).

Bright yellow is reported as attractive to $A$. variegatus beetles (Matioli \& Figueira, 1988; Gonçalves, 1997). Several yellow traps attract and capture A. variegatus (Matioli et al., 1990). From 1997 to 2003, a series of field experiments on the chemical ecology of D. speciosa and C. arcuata tingomariana (Ventura et al., 2000; 2001) were conducted and yellow traps caught non-target A. variegatus in some experiments. The responses of $A$. variegastus beetles to volatile floral attractants were studied in the field.

\section{MATERIAL AND METHODS}

A field assay was conducted in 2003 to evaluate the volatile dispenser ability to attract Diabrotica speciosa (Germ.) (Coleoptera: Chrysomelidae) beetles. The experiment also aimed to assess the effect of adding 1,4-dimetoxybenze and trans-cinnamaldeyde to 1,4dimetoxybenzene on captures. The experiment was carried out in Londrina $\left(23^{\circ} 19^{\prime} \mathrm{S}, 51^{\circ} 12^{\prime} \mathrm{W}\right)$, PR, Brazil. Common beans, Phaseolus vulgaris L., cv. IAPAR 59, sown on January 15, 2003 were used as testing sites. The traps consisted of plastic bottles (2 L) with 150 holes (5-mm diameter) yellow gold painted having inside a plastic strip $(3.5 \times 25.0 \mathrm{~cm})$ containing Lagenaria vulgaris (L.) powder $(0.28 \%$ cucurbitacin) - a feeding stimulant and arrestant for diabroticites sprayed with carbaril insecticide [Sevin 480 SC (2.25 $\mathrm{mL}$ per L)]. The bottom of the bottles was removed and an acrylic vial $(12.0 \times 12.0 \times 3.8 \mathrm{~cm})$ containing water and detergent was attached bellow to collect the dead insects. The treatments were 1,4dimethoxybenzene (one or two dispensers per trap), 1,4-dimethoxybenze + indole, 1,4-dimethoxybenzene + trans-cinnameldehyde and control $(\mathrm{n}=10)$. Traps were placed in the field on February 10, 2003. The population levels of $A$. viariegatus allowed the assessment of responses to volatile attractants. The volatile average release rate (over ten days) per dispenser was approximately $32 \mathrm{mg} \mathrm{day}^{-1}$ under laboratory conditions (Arruda-Gatti et al., 2006).

The experiment was conducted in a randomized complete block design. The distance between traps was $5 \mathrm{~m}$ within a block, and $10 \mathrm{~m}$ between blocks. An analysis of variance (ANOVA) was performed. Individual means were compared using Duncan's multiple range test (SAS Institute, 1989).

\section{RESULTS AND DISCUSSION}

The 1,4-dimethoxybenzene lured traps caught more beetles than the control in the first and second assessments (Table 1). Ten days after the onset of the experiment, there were no differences in the number of beetles caught by treatments probably due to the complete volatilization of the lure. Double dosages of 1,4-dimethoxybenzene did not improve beetle captures. Captures were higher in the 1,4dimethoxybenzene + cinnamaldehyde treatment than in 1,4-dimethoxybenzene only in the first assessment. Adding indole to 1,4-dimethoxybenzene did not improve beetle captures.

1,4-dimethoxybenzene is a major volatile floral chemical in Cucurbita maxima Duchesne cv. True Hubbard and the $4^{\text {th }}$ major component in Blue Hubbard floral volatile (Andersen, 1987). The neotropical $D$. speciosa is attracted by traps lured with 1,4dimethoxybenzene (Ventura et al., 2000). However, no records of attraction of North American Diabrotica inhabitants by 1,4-dimthoxybenzene have been reported although C. maxima blossoms do attract them (Metcalf

Table 1 - Mean number $( \pm \mathrm{SE})$ of Astylus variegatus caught per yellow traps baited with Cucurbita maxima blossom volatile attractants. Londrina, PR, 2002.

\begin{tabular}{|c|c|c|c|}
\hline Treatment & Feb $21^{\text {st }}$ & Feb $25^{\text {th }}$ & Feb $28^{\text {th }}$ \\
\hline 1,4-dimethoxybenzene ${ }^{1}$ & $112.5 \mathrm{~b}( \pm 51.45)^{3}$ & 37.2 a $( \pm 14.57)$ & $1.7 \mathrm{a}( \pm 0.85)$ \\
\hline 1,4-dimethoxybenzene ${ }^{2}$ & 88.7 b $( \pm 58.14)$ & $21.2 \mathrm{ab}( \pm 13.01)$ & $5.2 \mathrm{a}( \pm 3.04)$ \\
\hline 1,4-dimethoxybenzene ${ }^{1}+$ indole $^{1}$ & $76.0 \mathrm{~b}( \pm 34.21)$ & $19.5 \mathrm{ab}( \pm 7.18)$ & 4.5 a $( \pm 3.07)$ \\
\hline 1,4-dimethoxybenzene ${ }^{1}+$ cinnamaldehyde $^{1}$ & 188.2 a $( \pm 64.95)$ & 42.7 a $( \pm 15.72)$ & 9.2 a $( \pm 5.89)$ \\
\hline Control & $15.7 \mathrm{c}( \pm 14.11)$ & $2.5 \mathrm{c}( \pm 2.50)$ & 7.0 a $( \pm 6.35)$ \\
\hline
\end{tabular}

${ }^{1}$ One dispenser with approximately $32 \mathrm{mg}$ day ${ }^{-1} ;{ }^{2}$ Two dispensers with approximately $32 \mathrm{mg}$ day ${ }^{-1} ;{ }^{3}$ Means in the same column with different letters are different based on Duncan's multiple test $(P<0.05), \mathrm{n}=10$. 
\& Metcalf, 1992). D. speciosa and A. variegatus share the same pollen feeding habit in a similar geographic range, and similar response to volatile floral attractants would be predictable.

\section{CONCLUSIONS}

A. variegatus is attracted by 1,4dimethoxybenzene lured traps and captures are improved by adding cinnamaldehyde.

\section{REFERENCES}

ANDERSEN, J.F. Composition of the floral odor of Cucurbita maxima Duchesne (Cucurbitaceae). Journal of Agricultural and Food Chemistry, v.35, p.60-62, 1987.

ARRUDA-GATTI, I.C.; SILVA, F.A.C.; VENTURA, M.U. Responses of Diabrotica speciosa to a Semiochemical Trap Characteristics. Brazilian Archives of Biology and Technology, v.49, 2006.

BIANCO, R.. Pragas e seu controle, In: Gomes, J.; Gerage, A.C.(Ed.). A Cultura do Milho no Paraná. Londrina: IAPAR, 1991. p.187-22.

GONÇALVES, P.A.S. Levantamento de insetos associados à batatadoce, Ipomoea batatas, com uso de armadilhas d'agua, em Ituporanga, SC. Anais da Sociedade Entomológica do Brasil, v.26, p.199-203, 1997.

MATIOLI, J.C.; FIGUEIRA, A.R.. Dinâmica populacional e efeitos da temperatura ambiental e precipitação pluviométrica sobre Astylus variegatus (Germar, 1824) e A. sexmaculatus (Perty, 1830) (Coleoptera; Dasytidae). Anais da ESALQ, v.45, p.125$142,1988$.
MATIOLI, J.C.; ROSSI, M.M.; CARVALHO, C.F. Ocorrência e distribuição mensal de Astylus variegatus (Germar, 1824) e $A$. sexmaculatus (Perty, 1830) (Coleoptera: Dasytidae) em alguns municípios do Estado de Minas Gerais. Anais da Sociedade Entomológica do Brasil, v.19, p.373-382, 1990.

METCALF, R.L.; METCALF, E.R. Plant kairomones in insect ecology and control. New York: Chapman and Hall, 1992. $169 \mathrm{p}$.

ROSSETTO, C.J.; ROSSETTO, D. Astylus variegatus (Germar, 1824) (Coleoptera Dasytidae) danificando sorgo. Bragantia, v.35, p.131-132, 1976.

SAS Institute. SAS/STAT. User's Guide, Version 6. 4.ed. Cary: SAS Institute, 1989. 943p.

SOUZA, B.; CARVALHO, C.F. Aspectos morfológicos do adulto de Astylus variegatus (Germar, 1824) (Coleoptera, Melyridae). Pesquisa Agropecuária Brasileira, v.29, p.689-694, 1994.

VENTURA, M.U.; MARTINS, M.C.; PASINI, A.. Responses of Diabrotica speciosa and Cerotoma arcuata tingomariana (Coleoptera: Chrysomelidade) to volatile attractants. Florida Entomologist, v.83, p.403-410, 2000.

VENTURA, M.U.; MELLO, E.P.; OLIVEIRA, A.R.M.; SIMONELLI, F.; MARQUES, F.A.; ZARBIN, P.H.G. Males are attracted by female traps: a new perspective for management of Diabrotica speciosa (Germar) (Coleoptera: Chrysomelidae) using sexual pheromone. Neotropical Entomology, v.30, p.361-364, 2001.

WILLEMSTEIN, S.C. An evolutionary basis for pollination ecology. Leiden: Leiden University Press, 1987. 425p. (Botanical Series, 10).

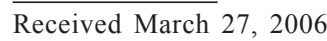

Accepted March 06, 2007 